\title{
"Energy efficiency and green solutions in sustainable development: evidence from the Norwegian maritime industry"
}

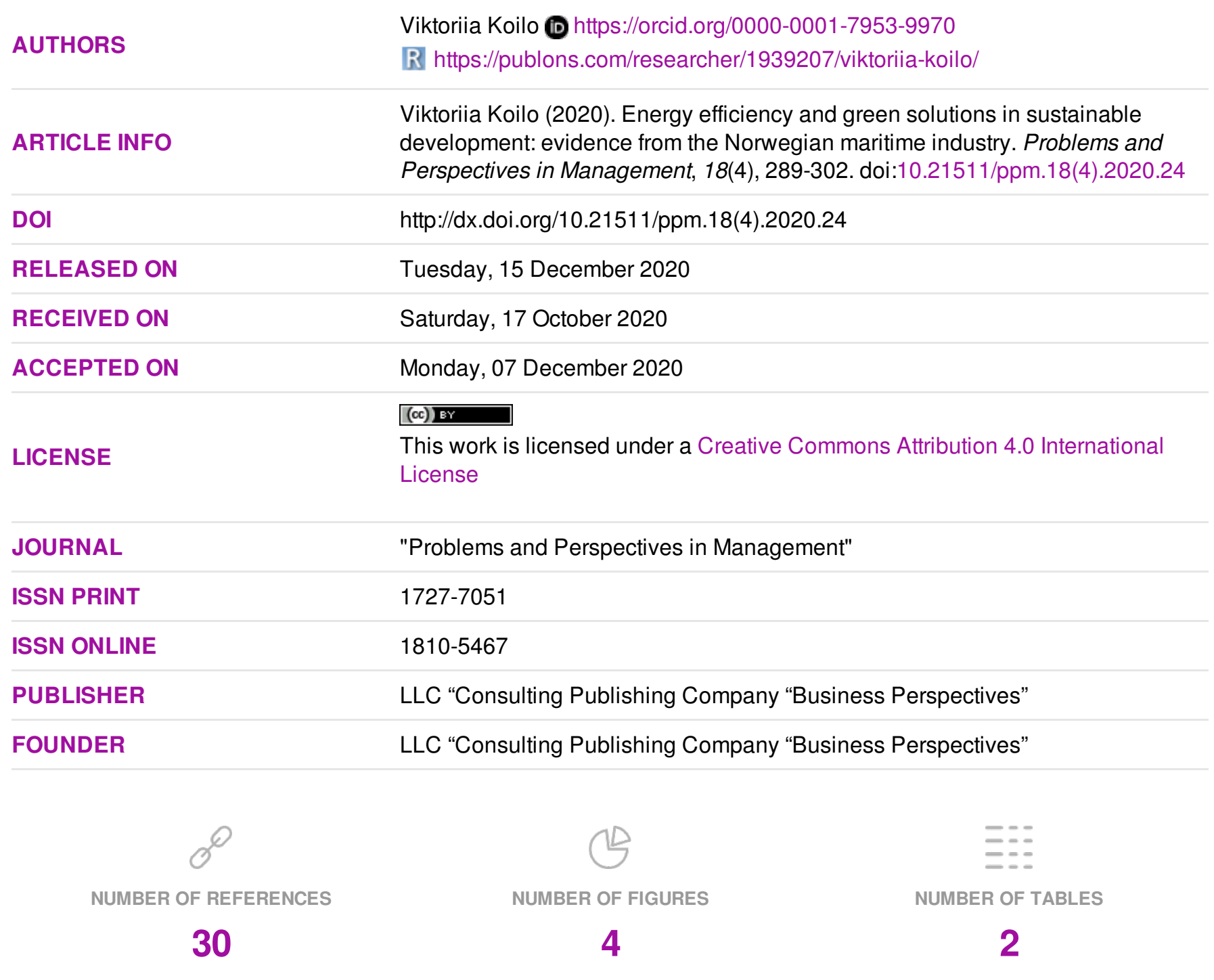

(C) The author(s) 2023. This publication is an open access article. 


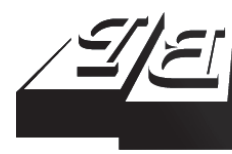

\section{BUSINESS PERSPECTIVES}

(O)

LLC "CPC "Business Perspectives" Hryhorii Skovoroda lane, 10 Sumy, 40022, Ukraine www.businessperspectives.org

Received on: $17^{\text {th }}$ of October, 2020 Accepted on: $7^{\text {th }}$ of December, 2020 Published on: $15^{\text {th }}$ of December, 2020

(c) Viktoriia Koilo, 2020

Viktoriia Koilo, Ph.D., Associate Professor, Department of Ocean Operations and Civil Engineering, Faculty of Engineering, Norwegian University of Science and Technology, Norway.

\section{ENERGY EFFICIENCY AND GREEN SOLUTIONS IN SUSTAINABLE DEVELOPMENT: EVIDENCE FROM THE NORWEGIAN MARITIME INDUSTRY}

\begin{abstract}
The maritime industry plays a special role in Norway. In recent years, it became subject to increasingly stronger requirements to reduce emissions. However, the most important is that the Norwegian maritime industry in several areas can deliver and further develop technology and products that provide lower emissions, nationally and globally. Going forward, technology development will be more important with time. Thus, it is important to find out what impact it will have on the industry's sustainable development and estimate the efficiency of new technologies.
\end{abstract}

This paper primarily aims to find a new optimization tool, which allows monitoring progress in the maritime industry towards sustainable development.

The present study reveals many new possible zero-emission solutions in the maritime industry, such as battery-electric architectures, ammonia, hydrogen, biofuel, and liquefied natural gas (LNG), liquefied petroleum gas (LPG), autonomous ships, etc. Moreover, it was highlighted that without active coordination between governance, academia, and industry, it is impossible to achieve international climate commitments and associated targets for reducing the emissions in the maritime industry.

In addition, in this study, a twofold model was proposed: the first part is the calculation of the Sustainable Development Index (SDI), and the last one is mathematical modeling, where the optimization variable carbon dioxide (CO2) emissions and Sustainable Development Index (SDI) should be maximized.

The investigation results prove that the model should be tested, and further research in this area is needed.

\section{Keywords}

green solutions, sustainable shipping, autonomous ships, ocean strategy, public support, optimization model

JEL Classification Q01, Q51, Q58, O33

\section{INTRODUCTION}

Nowadays the maritime industries make up a significant proportion of the Norwegian economy, and the sea is an important source of income for many coastal communities. Expertise and business environments connected to the oceans give Norway important competitive advantages in a global context. A future-oriented district policy is, therefore, also good maritime policy.

In 2015, the UN General Assembly launched the process of the developing agenda for sustainable development. As a result, 17 Sustainable Development Goals and 169 targets were created to promote social, environmental, and economic development. Agenda 2030 is the world's work plan, with goals that encourage measures to end hunger, achieve food security, good jobs, promote equality, contribute to innovation, safeguard biodiversity, provide access to clean energy, and mitigate 
the effects of climate changes. Sustainability Objective 14 encourages the world to implement measures to conserve and use marine resources to promote sustainable development. Contributing to achieving the sustainability goals is central to maritime industries at international, national, and local levels. Seventeen sustainability goals are connected and should be solved simultaneously.

Norway has comprehensive and responsible marine management and works to obtain a good international framework for sustainable management of the oceans. Digitization, automation, and globalization are important factors that affect both everyday work and the need for skills along the coast and the open seas. The era of groundbreaking technologies has been showing progress every day, strong improvement, and new capabilities.

The new century's problem is to find out the most efficient, cost-effective, and environmentally friendly solutions, which are extremely important in promoting sustainability. Besides, without clear governmental policy, financial mechanisms, and knowledge-based support, it is impossible to achieve the ambitious zero-emission goals in the maritime industry.

The current investigation is quite relevant. It can contribute to the existent studies from both theoretical and practical points of view, as far as it analyzes the most popular technologies in the maritime industry and proposes developing a new optimization tool to monitor progress in the industry towards sustainable development. Hence, studying energy efficiency, smart and sustainable green solutions is an important issue for research.

\section{THEORETICAL BASIS}

\subsection{Public support towards blue growth}

The maritime industries' success and opportunities in international markets is of great importance for Norway's prosperity. The country takes an active part in the development of international framework conditions.

The Norwegian Government's Ocean Strategy "New Growth, Proud History" was presented in 2017. Obviously, the authorities have high ambitions for the development at sea, and the policy is constantly evolving (Regjeringen, 2017b).

It should be noted that the Norwegian government is constantly pursuing an active policy in the field of supporting the maritime industry. The most famous strategies over the last two decades were (OECD, 2017): Maritime strategy 2007 "Steady as she goes", then in 2010 the Maritime 21 strategy was introduced. A continuation, supported by the new maritime strategy, was signed in 2015, called "Maritime Opportunities - Blue Growth for a Green Future". It was launched in 2016.
Implementation of all strategies mentioned above requires distinguishing the following two groups of selected support measures: 1) export credits and export guarantees; 2) support for research and development. A more detailed description is presented in Figure 1.

It should be noted that different public support schemes have been established to promote zero- and low-emission solutions. Examples of such schemes under process are Enova, Klimasats, and several schemes and programs under the Research Council of Norway and Innovation Norway.

The development of new technologies and markets is central to the transition to a low-emission economy, and in many areas, Norway is already well advanced. Support for developing and implementing zero-emission solutions in Norway can also contribute to solutions making low emissions cheaper. Thus, they can be adopted globally (Regjeringen, 2020).

The government also invests in Innovation Norway, contributing to the profiling of Norwegian green solutions, which can be spread internationally. Presently, there are three maritime clusters supported by Innovation Norway: Global Centers of 


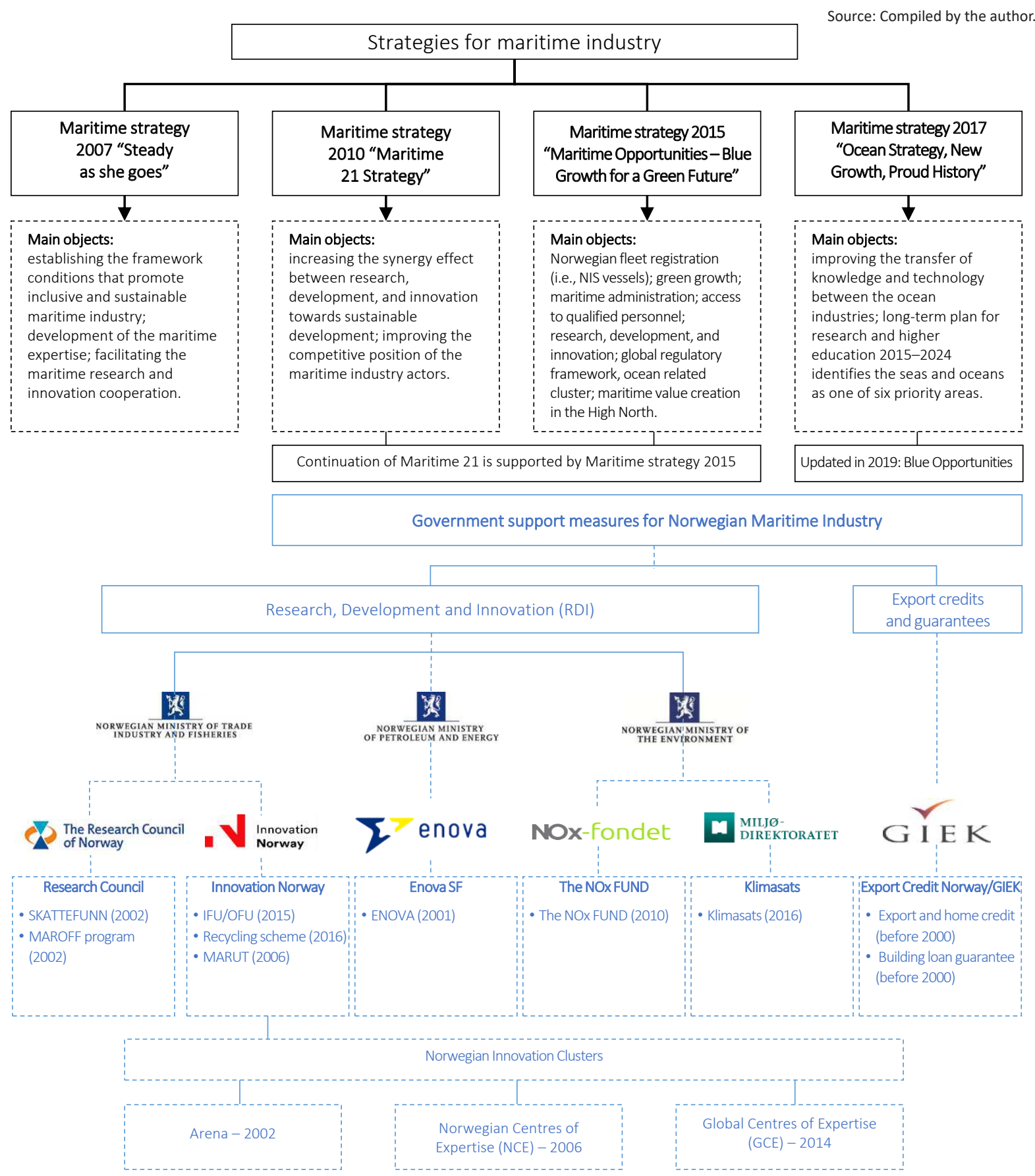

Figure 1. Norway's maritime strategies and government support measures

Expertise (GCE), Norwegian Centers of Expertise (NCE), and Arena (OECD, 2017).

Besides, there are several partnership programs between the private and public sectors, for example, the Green Shipping Program, which was launched in 2015 on the initiative of DNV GL. The program aims to facilitate the promotion of the most efficient and sustainable coastal shipping. The studies and pilots in the Green Shipping
Program help to identify and develop zero- and low-emission solutions that can be realized quickly. The work in the Green Shipping Program is divided into four phases and assessed the potential for battery and gas-based transport. Two studies were carried out, and five pilot projects were established, which investigated the possibility of environmentally friendly operational solutions. The focus was primarily on ship technical solutions (DNVGL, 2015). 
Hence, there are many possibilities for blue growth in the maritime industry, and lots of new green solutions are emerging in this area. Nevertheless, it is important to find more sustainability-friendly technologies, which ones help achieve ambitious goals concerning reducing $\mathrm{CO} 2$ (carbon dioxide) emissions, and at the same time can be made as cost-effectively as possible to contribute to higher value creation in the industry.

A report of DNVGL (2020) stated: "All maritime stakeholders will be challenged to significantly reduce GHG (greenhouse gas) emissions, forcing strategic choices, many of which will need to be made well before 2030, on low- to zero-carbon fuels and technologies to meet the IMO goals for 2050". Meanwhile, one does not know what kind of impact it will have on the industry's sustainable development. Except for the environmental dimension, there are also economic and social aspects, which should be considered, especially when it comes to the efficiency of new technologies.

\subsection{New green solutions in the maritime industry}

For a long time, Norway has been taking a leading position in the development of new green shipping technology. There are many ambitious goals to facilitate a competitive, efficient, safe, and environmentally friendly sea transport, with efficient ports and fairways and good preparedness against acute pollution. Increased use of new technological solutions in shipping and stimulation of green growth for the Norwegian maritime industry, among other things, using environmentally-friendly fuel, will be an important contribution to utilizing a future competitive advantage of shipping.

The Norwegian maritime industry has developed many new green solutions for shipping in recent years. An important point for shipping emissions is that the size of vessels is decisive for fuel consumption and emissions. The world's largest ships make up only 30 percent in number but account for 70-80 percent of the emissions (Norsk klimastiftelse, 2020). This means that to cut emissions in international shipping as much as possible, one needs alternatives to oil and diesel that are also suitable for the largest container ships, bulk ships, and tankers.
It presupposes further green restructuring in shipping. In particular, the use of batteries has developed rapidly in Norwegian short sea shipping, often in hybrid solutions where battery packs are used as a supplement to ordinary fuel. Full-electric ships have so far primarily entered the short distance ferry segment (Innovasjon Norge, 2020).

Enova launches a simple support scheme where companies in fisheries, aquaculture, and offshore can receive financial support for installing batteries and shore power systems in both new and existing vessels. The goal is to accelerate emission reductions at sea.

Green shipping is a priority for the government. Enova is one of several important tools that the government uses to support the industry through this restructuring process. For several years, Enova had offered support for various measures that can cut fuel consumption in vessels, including batteries. The long-term goal for Enova's investment in battery-electric solutions at sea is that zero-emission vessels should become competitive with conventional technology and are preferred by the market even without public support (Enova, 2020).

The largest emission reduction potential is found in the ship segments ferries, speedboats, aquaculture, and offshore vessels. Due to the spread in usage patterns, the measures in each segment contain several different technologies. Due to the large variation in the ships' energy needs, it is not possible to plan, for example, to implement battery electrification on all ships. Additional technologies, which should also be considered, are ammonia, hydrogen, biofuel, liquefied natural gas (LNG), and liquefied petroleum gas (LPG). In addition to the specific measures for different ship segments, shore power is a measure with a significant emission reduction potential since a significant part of the energy consumption from ships takes place when they are at the quay.

Hydrogen has also received much attention in recent years, and the first full-breed hydrogen vessels will probably be built and put into operation from 2021.

Hydrogen has a higher energy density than a battery and is better suited for larger ships that will sail over 
longer distances. Currently, the supply of hydrogen is a critical point. So far, there is no infrastructure along the coast where ships can fill hydrogen (Sunnmørsposten, 2020).

For international ('deep-sea') shipping, solutions such as ammonia and LNG receive the most attention. Why is ammonia the most promising alternative fuel? It is especially the costs of the various fuels and the engine/propulsion system's price that makes ammonia come out well in DNV GL's forecast. Ammonia, which consists of nitrogen and hydrogen (NH3), has a higher energy density than many other alternative fuels. There is already a significant production and infrastructure for transporting ammonia in place, since ammonia is used in fertilizer production and other chemical processes (Norsk klimastiftelse, 2020).

One of the main trends that are becoming increasingly prevalent in the coming years for the maritime industry is the increased digitalization and automation. This will change traditional operating patterns and the need for expertise.

As stated in Meld. St. 38 (2016-2017), shipping of the future will be strongly affected by major changes that are taking place in digitization and automation. Maritime authorities must contribute to the development, approval, and implementation of new solutions, and Information and communication technology (ICT) security will be an important consideration (Regjeringen, 2017a).

The overall and long-term goal of transport policy is a secure transport and communication system that promotes value creation and contributes to the transition to a low-emission economy.

There are currently many debates around the use of ICTs, as far as digitization and automation require more and more energy consumption.

In some recent studies, the influence of Industry 4.0 on sustainability was investigated, and it was stated that in European countries there is a negative relationship between ICT parameters and energy consumption that really tells about "the active implementation of energy-saving technologies", when countries with emerging economy showed other results (Koilo, 2019a).
Grytten et al. (2020) made estimates of the relationship between energy intensity and gross domestic product per capita in Norway for 18352019. It was proved that the environmental effect of energy depends on its production source. The study results showed that after the 1880s, with the introduction of hydroelectric power, Norwegian energy consumption became more sustainable. "Hence, energy consumption and intensity are not necessarily telling a story of environmental degradation" (Grytten et al., 2020)

Digitalization has largely been about big data, automation, artificial intelligence, and communication technologies in the maritime sector. All these technologies are central to the development of autonomous vessels that can contribute to large reductions in operating costs for maritime transport. The Norwegian maritime industry has been active in developing digital technologies, including several demonstration projects for autonomous vessels. The introduction of autonomous ships will help reduce accidents and the risk of oil spills. Simultaneously, it will trigger the development of new environmentally-friendly vessel types that reduce the cost of transporting goods by sea. Benefits are zero emissions, flexible services, manageable investments, and low transport costs.

Some believe that autonomous ships will be completely autonomous from day one, but the vessels will usually be under continuous supervision from the land. Control centers will monitor them and intervene if the automation has problems it cannot solve. Represented by NTNU and SINTEF, Norway has been out early with research on autonomous ships. The country has the world's first test area for such ships, in the Trondheim Fjord. In the Norwegian Forum for Autonomous Ships (NFAS), Norway has managed to mobilize large parts of its maritime cluster. The technology needed in autonomous ships is mainly available worldwide but must be tested and qualified (Gemini, 2017). For this reason, there was established a world-leading research and innovation center for demanding marine operations - SFI (Centre for Research-based Innovation). Presently SFI MOVE increases the cooperation with NTNU and AMOS (Centre for Autonomous Marine Operations and Systems). 
The idea is to optimize operations, from planning to execution, by better understanding the responses. This is a simulation-oriented approach where models are re-used throughout the value chain. The plan is to install needed sensors and technology in NTNU's research vessel Gunnerus and set up a ship owner control center in Ålesund. Using this approach, it will be possible to run experiments; design new solutions, implement, test, and observe the effect of new solutions. The goal is to test solutions in cooperation with one of the shipowners as partners (SFI MOVE, 2019).

At the same time, an increased level of digitalization and control creates two important challenges. One is about the ability to filter important information, and the other is about capturing the complexity of the work. This creates a greater potential for a mismatch between the description of the task in digital systems and what is actually needed to perform the task. This challenge is exacerbated when entering new markets with new requirements and when workers no longer have homogenous expertise (Giskeødegård \& Kjersem, 2020).

Hence, based on these predictions, one can see the following benefits and challenges in remote operations. One finds the following benefits: improved quality of operations by access to needed competence; reduced cost due to reduced crew on board. Simultaneously, the introduction of new technologies such as IIoT, cloud computing, digital twins, and $\mathrm{AI}$ increases the importance of knowledge in cybersecurity, require new regulations and new competencies of crew performance (SFI MOVE, 2019).

Indeed, automation promises to achieve the reduction of cost and risk involved in maritime operations, but at the same time, it can lead to new sources of error, especially when it comes to human operators and challenges connected to the highly automated systems (Zghyer et al., 2019).

Recent studies revealed that there had been conducted several analyses to evaluate critical awareness in maritime operations. It has been proved that human errors have been established as one of the main threats to marine safety. Hence, several methods have developed that will accelerate staff training progress without losing quality (Mao et al., 2019).
Thus, the SFI center aims to support the entire marine operation value chain by developing knowledge, compute tools, and methods that will be implemented in a simulator environment to pretest the marine operations, including the human component (SFI MOVE, 2019).

To sum up, nowadays there are many insights concerning new technologies in the maritime industry and lots of investigations were done in this area. Nevertheless, it is still needed to analyze the new green solutions' efficiency and their contribution to achieving SDGs.

Hence, this paper aims to find a new optimization tool to monitor progress in the industry towards sustainable development, i.e., the model will enable to determine the maximum level of $\mathrm{CO} 2$ emissions that can help ensure the achievement of at least a minimum level of sustainability.

\section{RESULTS}

The mentioned above reveals that the Norwegian marine technology and marine equipment industries are closely collaborating with shipping companies to produce power plants and further innovative solutions to meet new emission requirements.

Thus, considerable attention is paid to the development of vessels using batteries and lower fuel consumption. In Norway, there has been a significant increase in environmental investment in shipping due to an increase of tax on $\mathrm{CO} 2$, sulfur, and NOx and an introduction of international environmental standards for marine vessels and domestic environmental requirements for ferry services on public roads.

In this light, the Norwegian government seeks to reduce emissions associated with inland navigation activities, since inland navigation emissions were within the scope of the Paris Agreement (signed on the 21st yearly session of the Conference of the Parties (COP21), main aim - reduction of climate change). On the other hand, although provisions relating to the international shipping sector are not included in the COP21 agreement, IMO has developed international environmental standards regarding greenhouse gas emissions, SOx and NOx. 
To facilitate efforts to limit global warming and achieve the goals of the Paris Agreement, ocean mitigation options have been developed by specialists and described in the report "The Ocean as a Solution to Climate Change: Five Opportunities for Action" (Hoegh-Guldberg, 2019).

The world has already become 1.5 degrees warmer compared to pre-industrial times. The main reason why the temperature rises is that one emits more $\mathrm{CO} 2$ into the atmosphere from burning coal, oil, and gas. The message from the UN Climate Panel is clear: emissions must be halved by 2030 and reach zero around 2050 if one is to have a chance of limiting global warming to well below two degrees (Norsk klimastiftelse, 2020).

Figure 2 shows the potential for reducing emissions for six ocean climate action areas, including individual mitigation options for 2030 and 2050.

The report "The Ocean as a Solution to Climate Change: Five Opportunities for Action" (HoeghGuldberg, 2019) includes an assessment of four aspects of sustainable development and indicates all consequences of reducing the emissions (Table 1).

The assessment is based on a literature review and shows that ocean-based mitigation options have both advantages and tradeoffs. Nevertheless, there are more positive aspects, and environmental impact includes high biodiversity benefits for marine and terrestrial ecosystems, increased fisheries productivity and coastal tourism, reduced risk of ocean acidification, increased coastal resilience, and reducing water usage.

It should be noticed that the empirical evidence shows that the links between $\mathrm{CO} 2$ emissions and the maritime industry are strong, and since the 1990s, Norway started to invest in green solutions, hence, to keep sustainability direction (Koilo, 2019b).

At the same time, it is obvious that sustainability is a fragile and elusive state, a miraculous balancing act between the three competing aspects, a compromise that is difficult to achieve and even more difficult to maintain: “...over the years after the Kyoto Protocol, corporations still find it difficult to implement comprehensive change and even more so to drive strategic innovation for sustainability" (Emblemsvåg, 2016).

Thus, an important question is "whether the maritime industry has the right competence, capacity and willingness to continue to exploit these megatrends to reduce costs, keep a steady, sustainable course towards the low-emission society, increase market shares and gain competitiveness" (Jakobsen, Baustad, \& Mellbye, 2018).

Source: Compiled by the author based on Hoegh-Guldberg (2019).

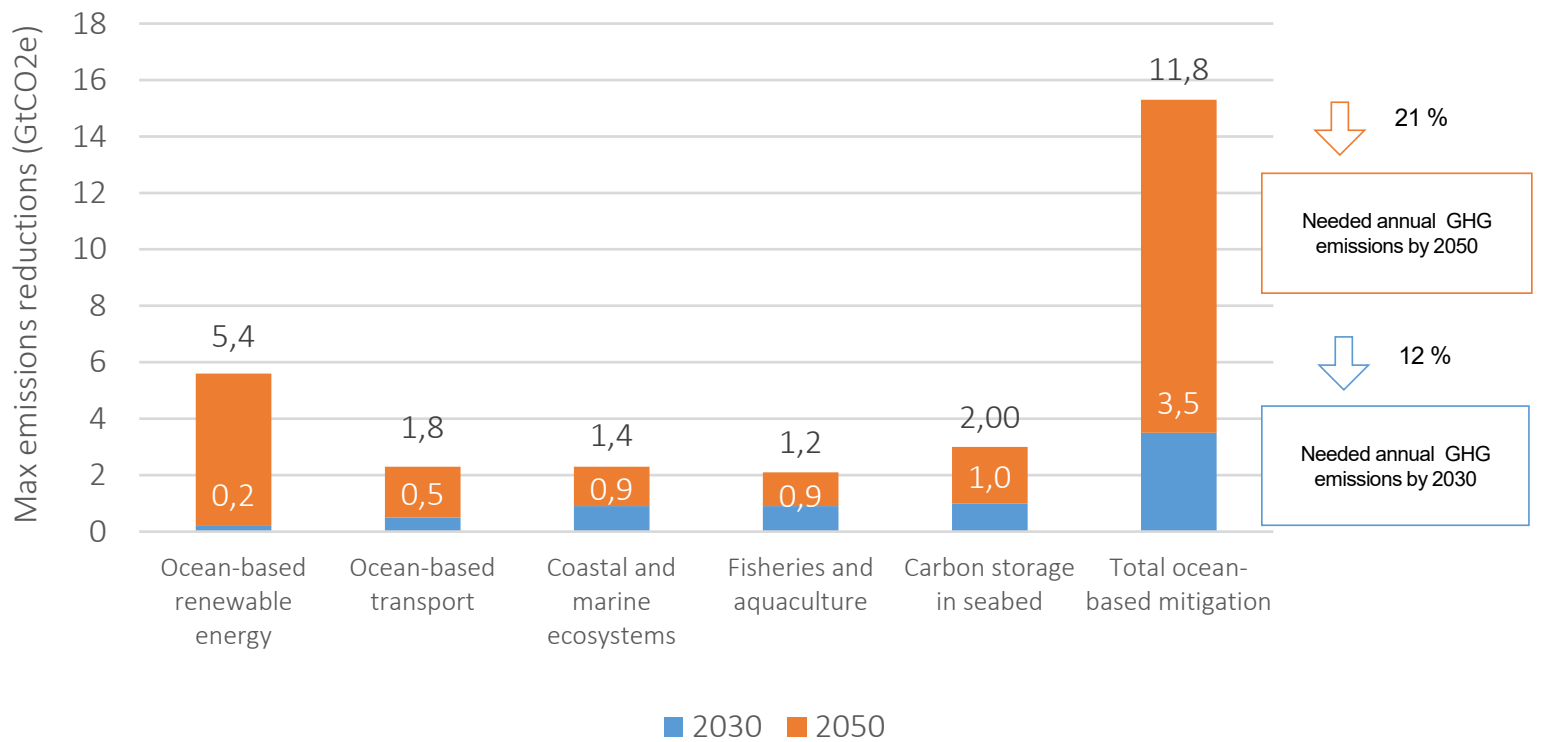

Figure 2. Mitigation of climate change in 2030 and 2050 
Table 1. Impact of the ocean-based climate actions on the achievement of SDGs

\begin{tabular}{|c|c|c|c|c|c|c|c|c|c|c|c|}
\hline \multirow{3}{*}{\multicolumn{2}{|c|}{$\begin{array}{l}\text { Sustainable } \\
\text { Development Goals } \\
\text { (SDGs) }\end{array}$}} & \multirow{2}{*}{\multicolumn{2}{|c|}{$\begin{array}{c}\begin{array}{c}\text { Ocean-based } \\
\text { renewable } \\
\text { energy }\end{array} \\
\text { Impact }\end{array}$}} & \multirow{2}{*}{\multicolumn{2}{|c|}{$\begin{array}{c}\text { Ocean-based } \\
\text { transport }\end{array}$}} & \multirow{2}{*}{\multicolumn{2}{|c|}{$\begin{array}{c}\begin{array}{c}\text { Coastal } \\
\text { and marine } \\
\text { ecosystems }\end{array} \\
\text { Impact } \\
\end{array}$}} & \multirow{2}{*}{\multicolumn{2}{|c|}{$\begin{array}{c}\begin{array}{c}\text { Fisheries } \\
\text { and } \\
\text { aquaculture }\end{array} \\
\text { Impact }\end{array}$}} & \multirow{2}{*}{\multicolumn{2}{|c|}{$\begin{array}{c}\begin{array}{c}\text { Carbon } \\
\text { storage in } \\
\text { seabed }\end{array} \\
\text { Impact }\end{array}$}} \\
\hline & & & & & & & & & & & \\
\hline & & "-" & "+" & "-" & "+" & "-" & "+" & "-" & "+" & "-" & "+" \\
\hline \multirow{4}{*}{ Economy } & SDG 7 & & & & & & & & & & \\
\hline & SDG 8 & & & & & & & & & & \\
\hline & SDG 9 & & & & & & & & & & \\
\hline & SDG 11 & & & & & & & & & & \\
\hline \multirow{4}{*}{ Environment } & SDG 6 & & & & & & & & & & \\
\hline & SDG 12 & & & & & & & & & & \\
\hline & SDG 14 & & & & & & & & & & \\
\hline & SDG 15 & & & & & & & & & & \\
\hline \multirow{6}{*}{ Society } & SDG 1 & & & & & & & & & & \\
\hline & SDG 2 & & & & & & & & & & \\
\hline & SDG 3 & & & & & & & & & & \\
\hline & SDG 4 & & & & & & & & & & \\
\hline & SDG 5 & & & & & & & & & & \\
\hline & SDG 10 & & & & & & & & & & \\
\hline \multirow{2}{*}{ Governance } & SDG 16 & & & & & & & & & & \\
\hline & SDG 17 & & & & & & & & & & \\
\hline
\end{tabular}

Obviously, there is a need for measuring and monitoring the suitability level in the maritime industry.

To achieve this, it has been developed the model, which helps to monitor progress in the maritime industry towards sustainable development. This tool can help determine the maximum level of $\mathrm{CO} 2$ emissions, which allows us to achieve at least a minimum level of sustainability in the maritime industry.

The methodology has series of steps and can be divided into two parts, which represented in Figure 3: (P.1) is a calculation of the Sustainable Development Index (SDI), and the last one (P.2) is mathematical modeling, where the optimization variable is $\mathrm{CO} 2$ emissions, and SDI level should be maximized.

Model (P.1). Firstly, there should be considered a set of indicators, which reflect different aspects of sustainable development: economy $(E c)$, society $(\mathrm{So})$, governance $(\mathrm{Go})$, and environment $(\mathrm{En})$ (Table 2). To make them comparable, one has to standardize the indicators. It should be noted that stimulating indicators in the model are operationalized as natural normalization; as destimulating indicators, one uses savage normalization (Koilo et al., 2020).
Table 2. Set of indicators reflecting the level of sustainable development in the maritime industry

\begin{tabular}{|c|c|c|}
\hline Category & Indicator & Description \\
\hline \multirow{3}{*}{ Economy $(E c)$} & $x_{1}$ & Value-added growth rate (\%) \\
\hline & $x_{2}$ & Contribution to GDP (\%) \\
\hline & $x_{3}$ & $\begin{array}{l}\text { Exports of goods and services } \\
\text { (US\$) }\end{array}$ \\
\hline \multirow{3}{*}{ Society (So) } & $\mathrm{x}_{4}$ & $\begin{array}{c}\text { Expenditure on training skills } \\
\text { growth rate }(\%)\end{array}$ \\
\hline & $x_{5}$ & Employment growth rate (\%) \\
\hline & $x_{6}$ & Income distribution (0-1) \\
\hline \multirow{3}{*}{ Governance $(G o)$} & $x_{7}$ & $\begin{array}{c}\text { Representatives of major } \\
\text { groups in national councils for } \\
\text { sustainable development (yes/ } \\
\text { no) }\end{array}$ \\
\hline & $x_{8}$ & $\begin{array}{c}\text { Sustainable development } \\
\text { strategies (yes/no) }\end{array}$ \\
\hline & $x_{9}$ & $\begin{array}{l}\text { Programs for industry's } \\
\text { environmental statistics and } \\
\text { indicators for sustainable } \\
\text { development (yes/no) }\end{array}$ \\
\hline \multirow{3}{*}{ Environment (En) } & $x_{10}$ & $\begin{array}{l}\text { Environment protection } \\
\text { expenditure to GDP }(\%)\end{array}$ \\
\hline & $x_{11}$ & Emissions of $\mathrm{CO} 2(\mathrm{t})$ \\
\hline & $x_{12}$ & Emissions of $\mathrm{NO}_{\mathrm{x}}(\mathrm{t})$ \\
\hline
\end{tabular}

On the second step, it is aimed to calculate the indexes of sustainable development in the following directions: economy $(E c)$, society $(S o)$, governance $(G o)$, and environment $(E n)$. 
Step 1. Normalization of indicators, which reflect different aspects of sustainable development: economy $(E C)$, society (So), governance (Go), and environment (En)

Step 2. Calculation of the sub-indexes of the sustainable development

Step 3. Sustainable Development Index (SDI) assessment

\begin{tabular}{lc|}
\hline Stimulating: & $x_{i j}(s t)=\frac{y_{i j}}{\max \left(y_{i j}\right)}$, \\
Destimulating: & $x_{i j}($ des $)=\frac{\min \left(y_{i j}\right)}{y_{i j}}$. \\
\hline & $R_{\text {category }}=\sum_{i=1}^{n} x_{i(\text { category })}$ \\
\hline & $S D I=\sqrt[4]{E c \cdot S o \cdot G o \cdot E n}$ \\
\hline
\end{tabular}

\section{Model (P.2): Determine the maximum level of $\mathrm{CO} 2$ emissions}

Step 1. Formalization of the dependency of sustainable development $(S D I)$ of the industry on the indicators of environmental performance $(E n)$ and indicator of nonenvironmental performance $(N / E n)$, such as economy, governance, and society

Step 2. Presenting a one-factor equation dependency of the indicators of environmental performance ( $E n$ ) on sustainable development $(S D I)$

Step 3. Determination of the lags of environmental performance (En); sustainable development index $(S D I)$ and the level of (CO2) emissions

Step 4. Formalization of the multifactor autoregressive model of the level of (CO2) emissions

Step 5. Presenting the condition of ensuring the minimum level of sustainable development $(S D I)$, based on optimization variable - (CO2) emissions in achieving the desired level of sustainability

Step 6. Determination of the multiple-factor optimization function that is based on determining the maximum level of carbon dioxide ( $\mathrm{CO} 2$ ) emissions and ensuring the minimum level of sustainability

$$
\left.S D I=\phi_{1} E n+\phi_{2}\left(\phi_{1}\right) N / E n\right)
$$

$$
\varphi_{2}\left(\varphi_{1}\right)=a_{1} \varphi_{1}^{n-1}+a_{2} \varphi_{1}^{n-2}+\ldots+a_{n}
$$

$$
\begin{aligned}
& \max (C O 2)_{t}=\beta_{0}+\sum_{m=1}^{n} \beta_{m}(C O 2)_{t-m}+ \\
& \sum_{m=0}^{n} \beta_{m+n}(E n)_{t-m}+\sum_{m=0}^{n} \beta_{m+2 n}(S D I)_{t-m}
\end{aligned}
$$

$$
\operatorname{SDI}\left(\phi_{1}\right) \leq\left(\min S D I\left(\phi_{1}\right)-\Delta F_{1}\right) \operatorname{SDI}\left(\phi_{1}\right)
$$

$$
\begin{aligned}
& \left\{(\mathrm{CO} 2)_{\mathrm{t}}=\beta_{0}+\sum_{m=1}^{n} \beta_{\mathrm{m}}(\mathrm{CO} 2)_{\mathrm{t}-\mathrm{m}}+\sum_{m=0}^{n} \beta_{m+n}(E n)_{t-m}+\sum_{m=0}^{n} \beta_{m+2 n}(S D I)_{t-m} \rightarrow \max \right. \\
& S D I=\phi_{1} E n+\left(a_{1} \phi_{1}^{3}+a_{2} \phi_{1}^{2}+a_{3} \phi_{1}+a_{4}\right) \cdot N / E n \rightarrow \min \\
& (\mathrm{CO} 2)_{t}=\beta_{0}+\sum_{m=1}^{n} \beta_{m}(\mathrm{CO} 2)_{t-m}+\sum_{m=0}^{n} \beta_{m+n}(E n)_{t-m}+\sum_{m=0}^{n} \beta_{m+2 n}(N / E n)_{t-m} \rightarrow \max \\
& \int \operatorname{SDI}\left(\varphi_{1}\right) \geq\left(\min \operatorname{SDI}\left(\varphi_{1}\right)-\Delta F_{1}\right) \\
& \left\{\frac{\partial S D I\left(\varphi_{1}\right)}{\partial \varphi_{1}}=E n+\left(a_{1} \varphi_{1}^{3}+a_{2} \varphi_{1}^{2}+a_{3} \varphi_{1}+a_{4}\right) \cdot N / E n\right. \\
& (\mathrm{CO} 2)_{t}=\beta_{0}+\sum_{m=1}^{n} \beta_{m}(\mathrm{CO} 2)_{t-m}+\sum_{m=0}^{n} \beta_{m+n}(E n)_{t-m}+\sum_{m=0}^{n} \beta_{m+2 n}(N / E n)_{t-m} \rightarrow \max \\
& \int \operatorname{SDI}\left(\varphi_{1}\right) \geq\left(\min \operatorname{SDI}\left(\varphi_{1}\right)-\Delta F_{1}\right) \\
& \left\{\varphi_{1}=\frac{-a_{2}(E n)+\sqrt{a_{2}^{2}(N / E n)^{2}-3 a_{1}(N / E n) \cdot(E n)-3 a_{1} a_{3}(N ? E n)^{2}}}{\left.3 a_{1}(N / E n)\right)}\right.
\end{aligned}
$$

Figure 3. Mathematical model for determining the maximum level of $\mathrm{CO} 2$ emissions

The final stage is the calculation of a Sustainable Development Index (SDI).

Model (P.2). The second part of the model aims to develop the methodology which can help to find out the optimal level of carbon dioxide (CO2) emissions, and at the same time, to ensure the condition of achieving at least a minimum level of sustainability in the industry. The model is comprised of the steps reflected in Figure 3. 
Thus, the calculation of this indicator gives the possibility to analyze the efficiency of the $\mathrm{CO} 2$ emissions policy towards achieving strategical sustainability goals. Besides, it is possible to estimate the progress of the decision-making management and use of new green technologies.

\section{DISCUSSION}

For centuries Norway has been one of the world's leading maritime nations. During the last decades, it has been taking a clear leadership position in the transition to green shipping. Green technology is developed along the entire coast and finds a market in Norway before scaled up and exported to the world.

The economic consequences of the corona crisis, combined with a fall in oil prices, are the most serious threats that have hit the Norwegian maritime industry in modern times. World-leading green expertise can erode if order books dry up. According to an estimate from Menon Economics (2020), every fifth employee in the industry is at risk of losing their job. The West Norway index reveals record-breaking pessimism among companies in Western Norway. It will have dramatic consequences for Norway as a maritime nation and the green shift. There is an urgent need for comprehensive and concrete counter-cyclical measures.
The maritime industry is currently working actively to identify ways to maintain jobs and activity in the industry. Through good cooperation with the industry, the government can now put in place the tools needed for an environmentally friendly upgrade of the fleet.

As it was mentioned before, there are many ways to reduce the environmental footprint. At the same time, there is a strong need to further investigate the effectiveness of those new green technologies. Thus, it's important to find technologies that are more sustainable friendly. Can this help to achieve ambitious goals concerning the reduction of $\mathrm{CO} 2$ emissions? At the same time, can they be cost-efficient and contribute positively to added value in the industry?

In a study by Bazari and Longva (2011), a model was designed to predict $\mathrm{CO} 2$ emissions levels to 2050. It is designed following the new mandatory measures to reduce GHG. According to their analysis, implementation of technologies and measures to reduce emissions and emission control rules will lead to a significant reduction of $\mathrm{CO} 2$ emissions in 2050: the results show that by 2030 and 2050, it is expected that the average annual reductions in $\mathrm{CO} 2$ emissions will be 330 and 1013 million tons, respectively, also it will result in a significant reduction in fuel consumption, but at the same time it will lead to deeper investments in smart vessels (Bazari \& Longva, 2011).

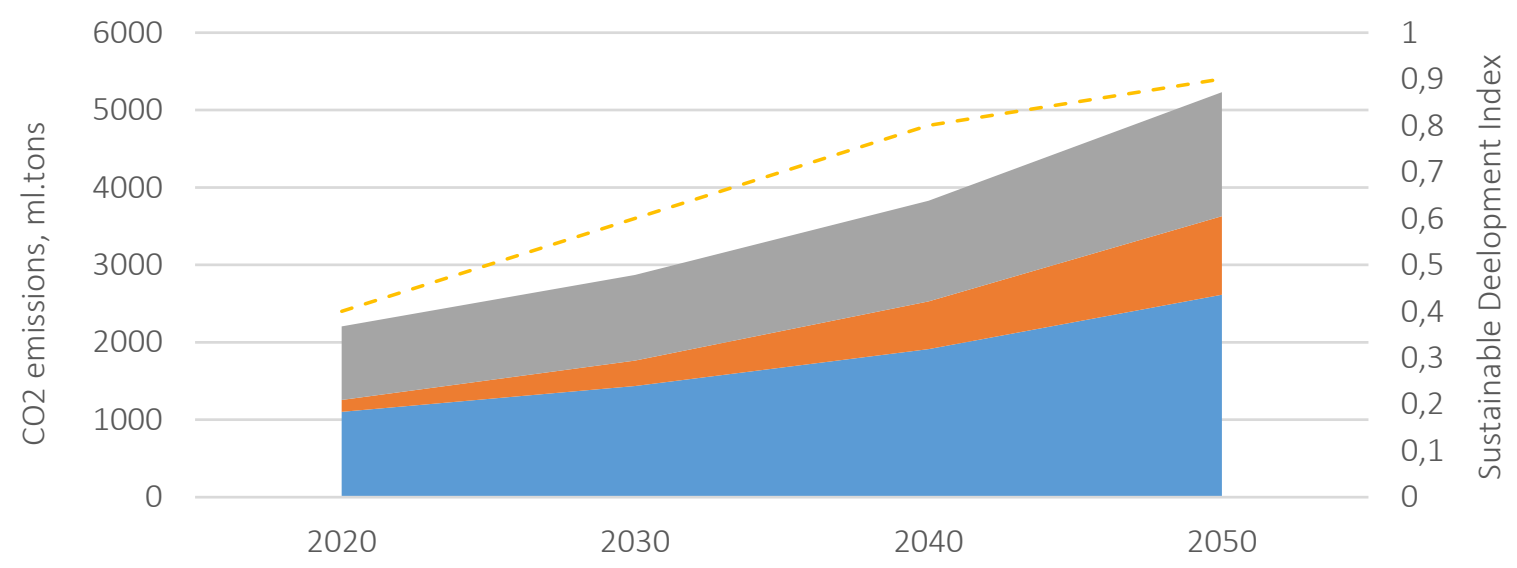

BAU, ml.tons $\quad$ Reduction, ml.tons $\quad \mathrm{NB}, \mathrm{ml}$.tons $\quad--$ SDI

Note: Business as Usual (BAU), New business (NB), Sustainable Development Index (SDI).

Figure 4. Estimated level of $\mathrm{CO} 2$ emissions reductions for world fleet and development of SDI, 2020-2050 
Hence, it is essential to assess the effectiveness of new environmental solutions from the point of sustainability: whether incentives will lead to improving the SDI as it is predicted in Figure 4, or whether they will have another tendency due to high level of costs on investment, energy intensity of sophisticated technologies, etc.

Thus, the proposed model can be exploited as an optimization tool, which allows monitoring progress in the maritime industry towards sustainable development.

Different researchers have already argued about the importance of the following investigations. For example, Ishchenko (2017) stated in his work that "Further research in this area should be directed at the analysis of possibilities to use various mathematical and economic models to formalize the stimulation of ecological and economic interactions and the promotion of green technologies".

It should be noted that the proposed model considers the calculation of SDI based on four dimensions, while the index is usually based on three dimensions: economy, society, and environment. Governance is the fourth dimension that is believed to be important in reflecting the institutional aspect. Skliar et al. (2020) confirm this statement in their study: "...based on 16 indicators identifying economic, social, and institutional aspects of sustainable development of Ukraine, it was found that institutional transformations contribute most to achieving sustainable development". Indeed, Makarenko et al. (2018), in their recent study, argue that public transparency is a serious factor for building an effective environmental development mechanism. The same statement can be found in the work of Kandrashina and Zotova (2018): "managerial decisions are drivers and cause the growth of the final project effectiveness", which confirms the importance of government support measures from the perspective of programs facilitation.

It is important to test the model, as it contains different dimensions of sustainability, not only environmental but also economical, which is important from the point of value creation, social, which reflects the wellbeing, and government aspects, which is important when it comes to developing policies directed towards sustainable development.

All the mentioned above proves that further research in this area is urgently needed. Thus, the model should be tested. At the same time, there are several limitations to be considered. For example, in order to find out the most effective solutions and to measure the level of their influence on sustainability, it's important to evaluate the level of the footprint of the smart vessels, which can be complicated from the practical point of view, especially when it comes to marine hybrid technologies, e.g., combining the improving vehicle design/ engineering (hybrid vessels, hydrogen fuel-cell engines, etc.) and traffic management.

Hence, to obtain more comprehensive results, future research should be expanded using additional research instruments, on the one hand, and a set of indicators of the model can be expended, on the other hand.

\section{CONCLUSION}

Norway has ambitious plans, i.e., significantly reduce GHG emissions and to meet the IMO goals for 2050 .

The main measure towards this is a rapid transition to zero-emission solutions. In a short perspective, streamlining can lead to emission reductions.

The present study reveals that the government's role is strong in forcing green solutions in the maritime industry. There is ongoing work with national maritime strategies. Together with the management plans for the Norwegian sea areas and other management documents, the government will continue with clear and comprehensive strategic investments within maritime industries. 
Moreover, the present study investigated new possible zero-emission solutions in the maritime industry and their impact on the sustainable development of the industry. In particular, the green revolution is creating new technologies. Thus, stakeholders are moving away from traditional fossil-energy-based power systems towards the use of batteries, natural gas (LNG), biogas, biofuels, hydrogen, use of autonomous vessels for emission-free transport, and sustainable smart logistic.

It was also mentioned that there is a significant role in the partnership programs between the private and the public sectors, along with educational and research institutions. One example is the research and innovation center for demanding marine operations (SFI). It aims to support the innovation process of the marine operations value chain by involving industry partners. Hence, improving the competitiveness of the Norwegian maritime cluster.

To sum up, there are many possibilities for blue growth in the maritime industry, and new green solutions are emerging in this area.

The impact of new technologies is still not fully investigated. One doesn't know its full impact on sustainable development of the industry, because except for the environmental dimension, there are also economic and social aspects, which should also be considered. They cannot be ignored, especially when it comes to the efficiency of new technologies.

Hence, an important question is whether the maritime industry can continue to exploit these megatrends to reduce costs, keep a steady, sustainable course towards low emissions, increase market shares, and gain competitiveness.

Thus, the paper proposes a new optimization tool, which allows monitoring progress in the maritime industry towards sustainable development. This model aims to determine the maximum level of CO2 emissions, allowing the achievement at least of a minimum level of sustainability in maritime industries.

\section{AUTHOR CONTRIBUTIONS}

Conceptualization: Viktoriia Koilo.

Data curation: Viktoriia Koilo.

Formal analysis: Viktoriia Koilo.

Funding acquisition: Viktoriia Koilo.

Investigation: Viktoriia Koilo.

Methodology: Viktoriia Koilo.

Project administration: Viktoriia Koilo.

Resources: Viktoriia Koilo.

Software: Viktoriia Koilo.

Supervision: Viktoriia Koilo.

Validation: Viktoriia Koilo.

Visualization: Viktoriia Koilo.

Writing - original draft: Viktoriia Koilo.

Writing - review \& editing: Viktoriia Koilo.

\section{ACKNOWLEDGMENT}

The research is supported by a grant from the Research Based Innovation "SFI Marine Operation in Virtual Environment (SFI-MOVE)" (Project no: 237929) in Norway. 


\section{REFERENCES}

1. Bazari, Z., \& Longva, T. (2011). Assessment of IMO Mandated Energy Efficiency Measures for International Shipping. Estimated $\mathrm{CO} 2$ Emissions Reduction from Introduction of Mandatory Technical and Operational Energy Efficiency Measures for Ships. Retrieved from https://www.schonescheepvaart. $\mathrm{nl} /$ downloads/rapporten/ doc_1362490668.pdf (accessed on November 20, 2020).

2. DNVGL. (2015). Grønt Skipsfartsprogram. Retrieved from https://www.dnvgl.no/maritime/ gront-skipsfartsprogram/index. html (accessed on November 17, 2020).

3. DNVGL. (2015). Impact on maritime. Retrieved from https://www. dnvgl.com/to2030/impact/impacton-maritime.html (accessed on November 20, 2020).

4. Emblemsvåg, J. (2016). The Role of the Government. In Reengineering Capitalism. Springer, Cham. https:// doi.org/10.1007/978-3-319-196893_8

5. ENOVA. (2020). Nå blir det lettere å få støtte til elektriske fartøy (Pressemelding). Retrieved from https://presse.enova.no/ pressreleases/naa-blir-det-lettereaa-faa-stoette-til-elektriske-fartoey-3047490 (accessed on November 7, 2020).

6. Gemini. (2017). Førerløse skip kan erstatte mange vogntog. Retrieved from https://gemini.no/2017/05/ forerlose-skip-erstatte-vogntog/ (accessed on November 1,2020).

7. Giskeødegård, M. F., \& Kjersem, K. (2020). «Det kan voere et veldig godt verktøy, hvis det fungerer»: en produksjonsorientert studie av potensialet for Augmented Realityløsninger i verftsindustrien. Digital samhandling: Fjordantologien. Retrieved from https://www.idunn.no/digital_ samhandling/8_det_kan_vaere_et_ veldig_godt_verktoey_hvis_det_ fungerer (accessed on November $18,2020)$.

8. Grytten, O. H., Lindmark, M., \& Minde, K. B. (2020). The wealth of nations and sustainable development: energy intensity and the environmental Kuznets curve. Environmental Economics, 11(1), 110-123. https://doi.org/10.21511/ ee.11(1).2020.10

9. Hoegh-Guldberg. O. (2019). The Ocean as a Solution to Climate Change: Five Opportunities for Action (Report). Washington, DC: World Resources Institute. Retrieved from http://www.oceanpanel.org/climate (accessed on July 17, 2019).

10. Innovasjon Norge. (2020). Rustet til restart. Innovasjonstalen 2020. Retrieved from https:// www.innovasjonnorge.no/ globalassets/0-innovasjonnorge.no/ om-innovasjon-norge/kort-om-oss/ innovasjonstalen/rustet-til-restart--innovasjonstalen-2020---rapport. pdf (accessed on November 2, 2020).

11. Ishchenko, A. (2017). Stimulation of effective ecological and economic interactions in the process of business environment creation. Environmental Economics, 8(2), 57-66. https://doi.org/10.21511/ ee.08(2).2017.06

12. Jakobsen, E. W., Baustad, H., \& Mellbye, C. (2018). Global Performance benchmark (Report). Menon publication 89/2018. GCE Blue Maritime. Retrieved from https:// www.bluemaritimecluster.no/ download?objectPath=/upload_images/D3591BDCAB4C444AB474CA1F4AD10826.pdf (accessed on July 18,2019 ).

13. Kandrashina, E., \& Zotova, A. (2018). Changes effectiveness assessment on the basis of sustainable development factor. Problems and Perspectives in Management, 16(1), 437-444. https://doi.org/10.21511/ ppm.16(1).2018.41

14. Koilo, V. (2019a). Evidence of the Environmental Kuznets Curve: Unleashing the Opportunity of Industry 4.0 in Emerging Economies. Journal of Risk and Financial Management, 12(3), 122. https:// doi.org/10.3390/jrfm12030122

15. Koilo, V. (2019b). Sustainability issues in maritime transport and main challenges of the shipping industry. Environmental Economics, 10(1), 48-65. https://doi. org/10.21511/ee.10(1).2019.04

16. Koilo, V., Ryabushka, L., Kubakh, T., \& Halik, J. (2020). Assessment of government debt security of emerging markets: theory and practice. Investment Management and Financial Innovations, 17(1), 35-48. https://doi.org/10.21511/ imfi.17(1).2020.04

17. Makarenko, I., Bychenko, D., Makarenko, S., \& Qasimova, G. (2018). Environmental responsibility mechanism development in the public sector of the economy. Environmental Economics, 9(3), 28-41. https://doi.org/10.21511/ ee.09(3).2018.04

18. Mao, R., Li, G., Hildre, H. P., \& Zhang, H. (2019) Analysis and evaluation of eye behavior for marine operation training - A pilot study. Journal of Eye Movement Research, 12(3).

19. Menon Economics. (2020). Prognoser for maritim noering per august 2020 (Rapport). Retrieved from http://s3-eu-west-1.amazonaws.com/maritimt-forum.no/ documents/Rapport-Prognoserfor-maritim-n\%C3\%A6ring-peraugust-2020.pdf

20. Norsk klimastiftelse. (2020). Grønn skipsfart: Utslippene må i null i 2050 (Rapport 1/2020). Retrieved from https://klimastiftelsen.no/publikasjoner/gronn-skipsfart-utslippenema-i-null-i-2050/ (accessed on November 18, 2020)

21. OECD. (2017). Peer Review of the Norwegian Shipbuilding Industry. Retrieved from http://www.oecd. org/sti/ind/PeerReviewNorway_FINAL.pdf (accessed on July 17, 2019).

22. Regjeringen. (2017a). IKTsikkerhet - Et felles ansvar (Meldinger til Stortinget, 38 (2016-2017)). Retrieved from https://www.regjeringen. no/no/dokumenter/meld.st.-38-20162017/id2555996/ (accessed on November 2, 2020).

23. Regjeringen. (2017b). The Norwegian Government's Ocean Strategy 
"New Growth, Proud History. Retrieved from https://www.regjeringen.no/contentassets/00f5d674cb68 4873844bf3c0b19e0511/the-norwegian-governments-ocean-strategy--new-growth-proud-history.pdf (accessed on October 17, 2020).

24. Regjeringen. (2019a).

Handlingsplan for grønn skipsfart.

Retrieved from https://www. regjeringen.no/contentassets/2ccd2 f4e14d44bc88c93ac4effe78b2f/handlingsplan-for-gronn-skipsfart.pdf (accessed on October 17, 2020).

25. Regjeringen. (2019b). Lov om havner og farvann (havne- og farvannsloven). Prop. 86 L (20182019). Retrieved from https://www. regjeringen.no/no/dokumenter/ prop.-86-1-20182019/id2640729/ (accessed on November 18, 2020).
26. Regjeringen. (2020).

Klimaendringer og norsk klimapolitikk. Retrieved from https://www.regjeringen.no/no/ tema/klima-og-miljo/innsiktsartikler-klima-miljo/klimaendringerog-norsk-klimapolitikk/id2636812/ (accessed on November 2, 2020).

27. SFI MOVE. (2019). Marine Operations - MOVE (Annual Report 2019). Retrieved from https:// www.ntnu.edu/move (accessed on November 21, 2020).

28. Skliar, I., Pedchenko, N., Strilec, V., Novikova, V., \& Kozmenko, Y. (2020). Assessment of the reforms and programs results of Ukraine's economy sustainable development by means of neural networks. Prob- lems and Perspectives in Management, 18(3), 81-92. https://doi. org/10.21511/ppm.18(3).2020.07

29. Sunnmørsposten. (2020). Havyard satser på hydrogen - oppretter eget selskap. Retrieved from https:// www.smp.no/nyheter/2020/11/20/ Havyard-satser-p\%C3\%A5hydrogen-oppretter-eget-selskap-23024120.ece (accessed on November 20, 2020).

30. Zghyer, R., Ostnes, R., \& Halse, K. H. (2019). Is Full-autonomy the Way to Go Towards Maximizing the Ocean Potentials? TransNav, International Journal on Marine Navigation and Safety of Sea Transportation, 13(1), 33-42. https://doi. org/10.12716/1001.13.01.02 